\title{
Disaster Response Among Hospital Nurses Dispatched To Evacuation Centers In And Beyond The Fukushima Prefecture
}

Chika Yamamoto ( $\sim$ chika.y.9112@gmail.com )

Minamisoma Municipal General Hospital

Katsuko Onoda

Minamisoma Municipal General Hospital

Arifumi Hasegawa

Fukushima Medical University School of Medicine

Tomoyoshi Oikawa

Minamisoma Municipal General Hospital

Masaharu Tsubokura

Fukushima Medical University School of Medicine

Research Article

Keywords: shelte, management, disaster, evacuation

Posted Date: October 5th, 2021

DOI: https://doi.org/10.21203/rs.3.rs-909960/v1

License: (9) This work is licensed under a Creative Commons Attribution 4.0 International License.

Read Full License 


\section{Abstract}

Introduction: Living in a shelter affects resident health, increasing mortality risk, making shelter management a crucial part of disaster response.

Multiple stakeholders are involved in managing evacuation centers. However, little is known about the support needs of medical personnel within a disaster area.

Methods: This study aimed to examine the role of nurses in this disaster response, including evacuation to shelters, and the challenges they faced, given the lack of previous training or experience. Semistructured interviews were conducted with nurses who were affected by the nuclear power plant accident, and qualitative content analysis was conducted.

Results: The challenges of shelter activities included the experience of being rebuffed by residents affected in the same area and the need to manage the conflict between the positions of victims and supporters. In addition, it was shown that by building support among staff and relationships between staff and residents, they were able to continue their difficult shelter activities. Many nurses expressed interest in disaster nursing, as their experiences of supporting people in disasters and evacuation centers provided them with hints for their nursing practice, and they applied the lessons learned from their evacuation center activities to their future disaster response.

Discussion: To improve staff management of trauma, suitable training should be provided during "normal" times to strengthen staff relationships; in addition, clinical and community nurses should be afforded opportunities to understand each other's roles to support disaster response.

\section{Introduction}

Disaster response requires complex medical and procedural interventions, including the management of hospitalized patients that are sick and injured, and those requiring emergency care, as well as handling hospital evacuation and transfer to shelters. Optimal disaster response is a public health challenge, as it directly affects survivorship. Living in a shelter affects resident health, ${ }^{1,2}$ increasing mortality risk, making shelter management a crucial part of disaster response.

Multiple stakeholders are involved in managing evacuation centers. ${ }^{3-5}$ However, shelters tend to be staffed by medical personnel from the disaster-affected area, including public health nurses, and local government officials, $\otimes^{7}, 7$ wich contribute knowledge about the area, medical supplies, and population health. These groups require adequate support. Previous reports ${ }^{8-10}$ have examined the types of support required by people outside a disaster area; however, little is known about the support needs of medical personnel within a disaster area.

The Great East Japan Earthquake that occurred on March 11, 2011 (earthquake), caused the accident at the Fukushima Daiichi Nuclear Power Plant (NPP). Minamisoma City in the Fukushima Prefecture is 
located north of the Fukushima NPP, with a radius of $12-38 \mathrm{~km}$. In addition to the damage caused by the earthquake and tsunami, many citizens of Minamisoma were forced to evacuate due to radiation disasters. The Fukushima NPP accident halted the distribution of goods in the city and resulted in bus evacuation of the residents to shelters within and outside of the Prefecture on March 18. In an unprecedented decision, the Minamisoma Municipal General Hospital (Fig. 1), located within $23 \mathrm{~km}$ of the city, dispatched its medical staff to evacuation centers where Minamisoma citizens were placed, depending on staff preference. Although this combination of disasters was historically unique, similar complex disasters are likely to occur in the future, requiring suitable response protocols. This study aimed to examine the role of nurses in this disaster response, including evacuation to shelters, and the challenges they faced, given the lack of previous training or experience.

\section{Materials And Methods}

Nurses that worked at the Minamisoma Municipal General Hospital at the time of the disaster and who were involved in evacuation to shelters were enrolled. Semi-structured interviews were conducted using an interview guide with 10 nurses. Study purpose and procedures were explained to the nurses, who provided their consent to participate.

\section{Data collection}

Confidential interviews were conducted between March and May 2020 for approximately 60 minutes. The following information was collected during the interview: 1) years of experience as a nurse at the time of the earthquake, 2) details of evacuation support activities, 3) difficulties encountered during evacuation, and associated management strategies; and 4) gains from the experience. Interviews were recorded and transcribed verbatim, and analyzed using descriptive qualitative research methods. ${ }^{11}$ Recordings were divided into meaningful segments, and divided into categories and sub-categories, based on the homogeneity and heterogeneity of semantic content.

\section{Statement}

The study adhered to the RATS guidelines on qualitative research.

\section{Ethics}

This study was approved by the Ethics Committee of the Minamisoma Municipal General Hospital (Approval number: 1-17) and the Ethics Committee of the Fukushima Medical University (Approval number: 2019-330),written informed consent was obtained from all research participants.

\section{Results}

This study included 10 nurses ( 9 women) who were working at the Minamisoma Municipal General Hospital at the time of the earthquake. The median number of nursing experience years at the time of the 
disaster was 11 (range: 5-20) years. All participants were new to disaster relief activities, including evacuation shelter support.

\section{Challenges in evacuation shelter activities}

One of the most difficult aspects of evacuation shelter support activities was the experience of being rebuked by residents who had experienced the disaster in the same area. The nurses felt that they were not accepted by the residents who were stressed by the disaster and dissatisfied with their shelters. In addition, the nurses felt they were not perceived as victims of the disaster, and that they had to manage the conflict between the positions of victim and supporter (Table 1).

Table1. Challenges in evacuation shelter activities 


\begin{tabular}{|c|c|c|}
\hline Categories & Subcategories & Codes \\
\hline \multirow[t]{4}{*}{$\begin{array}{l}\text { Experiences } \\
\text { of not being } \\
\text { accepted by } \\
\text { residents }\end{array}$} & $\begin{array}{l}\text { Experiences of being hurt } \\
\text { by residents' words }\end{array}$ & $\begin{array}{l}\text { Residents expressed their frustration at job loss, saying } \\
\text { to the medical staff, "You can work. We've lost our } \\
\text { jobs." This became an outlet for the residents' } \\
\text { frustration.(3) }\end{array}$ \\
\hline & \multirow{2}{*}{$\begin{array}{l}\text { Experiences of being an } \\
\text { outlet for residents' } \\
\text { dissatisfaction with the } \\
\text { government }\end{array}$} & $\begin{array}{l}\text { A nurse reported being shocked to hear residents say, } \\
\text { "You are a city employee" (1). }\end{array}$ \\
\hline & & $\begin{array}{l}\text { Residents told nurses how stressed they were by the } \\
\text { disaster, how dissatisfied they were with the shelters, } \\
\text { and how much they wanted to return home (3). }\end{array}$ \\
\hline & $\begin{array}{l}\text { Sadness at not being } \\
\text { seen as a fellow disaster } \\
\text { victim }\end{array}$ & $\begin{array}{l}\text { The nurses experienced being seen as "a public } \\
\text { servant" rather than a "fellow disaster victim" (4). }\end{array}$ \\
\hline \multirow[t]{2}{*}{$\begin{array}{l}\text { Conflicts in } \\
\text { multiple } \\
\text { positions }\end{array}$} & \multirow[t]{2}{*}{-} & $\begin{array}{l}\text { The nurses "continued to experience conflicts as a } \\
\text { mother, nurse, and city employee" in evacuation and } \\
\text { shelter activities (1). }\end{array}$ \\
\hline & & $\begin{array}{l}\text { The nurses were "seen by the residents as both a nurse } \\
\text { and city employee" (2). }\end{array}$ \\
\hline \multirow[t]{3}{*}{$\begin{array}{l}\text { Difficulties of } \\
\text { "firsts" }\end{array}$} & $\begin{array}{l}\text { Difficulties in working in } \\
\text { a field different from } \\
\text { clinical practice }\end{array}$ & $\begin{array}{l}\text { The nurses felt their "lack of knowledge" when } \\
\text { confronted with tasks that required a skillset different } \\
\text { from that required by routine clinical practice (2). }\end{array}$ \\
\hline & - & $\begin{array}{l}\text { The nurses "had never been involved" in disaster relief' } \\
\text { it was their first time working in an evacuation center } \\
\text { (7). }\end{array}$ \\
\hline & $\begin{array}{l}\text { Difficulties in making } \\
\text { decisions when } \\
\text { responding to individual } \\
\text { cases }\end{array}$ & $\begin{array}{l}\text { The lack of a procedural manual left the nurses } \\
\text { "puzzled" as to whether calling an ambulance may } \\
\text { cause trouble for the residents }(1) \text {. }\end{array}$ \\
\hline \multirow{2}{*}{$\begin{array}{l}\text { Working with } \\
\text { uncertainty of } \\
\text { the future }\end{array}$} & \multirow[t]{2}{*}{-} & $\begin{array}{l}\text { The nurses reported stress as "working with uncertainty } \\
\text { about the future" (2). }\end{array}$ \\
\hline & & $\begin{array}{l}\text { The nurses focused daily on "dealing with the } \\
\text { situation" (1), reporting it was "all [they] could do to } \\
\text { spend their days" (1). }\end{array}$ \\
\hline
\end{tabular}

\section{Factors that support the continuation of evacuation shelter support activities}

Interviewees were asked how they responded to difficult experiences during evacuation shelter activities. Some factors supported the continuation of these challenging activities. The staff used each other as a support system, which helped them deal with the potentially hostile response of the residents. The staff built relationships with the residents, who offered encouragement, supporting the continuation of evacuation activities (Table 2). 
Table 2

Factors that supported the continuation of evacuation shelter support activities

\begin{tabular}{|c|c|c|}
\hline Categories & Subcategories & Codes \\
\hline \multirow{3}{*}{$\begin{array}{l}\text { Carrying out } \\
\text { the role as a } \\
\text { nurse }\end{array}$} & Challenges & $\begin{array}{l}\text { I thought that taking care of the victims' health helped to } \\
\text { nurse them (2). }\end{array}$ \\
\hline & \multirow[t]{2}{*}{$\begin{array}{l}\text { Taking care of } \\
\text { residents' needs }\end{array}$} & $\begin{array}{l}\text { Alleviate the residents' anxiety requires kindness and active } \\
\text { listening (2). }\end{array}$ \\
\hline & & Residents want to be heard (5). \\
\hline \multirow{2}{*}{$\begin{array}{l}\text { Words from the } \\
\text { residents that } \\
\text { helped me feel } \\
\text { better }\end{array}$} & \multirow[t]{2}{*}{-} & $\begin{array}{l}\text { Some of the residents told me that they could talk to me } \\
\text { because I was from their hometown and that it made them } \\
\text { feel at ease.(2) }\end{array}$ \\
\hline & & $\begin{array}{l}\text { I was happy to speak to a nurse from my hometown } \\
\text { because I could understand her language (2). }\end{array}$ \\
\hline \multirow{6}{*}{$\begin{array}{l}\text { Strength of } \\
\text { Human } \\
\text { Connection }\end{array}$} & $\begin{array}{l}\text { Strengths in } \\
\text { having a family }\end{array}$ & $\begin{array}{l}\text { My family members were with me, so I felt a little reassured } \\
\text { (1). }\end{array}$ \\
\hline & \multirow{2}{*}{$\begin{array}{l}\text { Strength in having } \\
\text { friends }\end{array}$} & I was helped by the staff that went with me (1). \\
\hline & & $\begin{array}{l}\text { I felt more distracted when I was with my teammates than } \\
\text { when I was alone (2). }\end{array}$ \\
\hline & \multirow{3}{*}{$\begin{array}{l}\text { Strength in the } \\
\text { support of the } \\
\text { evacuation center } \\
\text { community }\end{array}$} & $\begin{array}{l}\text { There were events at the evacuation center, and I have many } \\
\text { good memories (2). }\end{array}$ \\
\hline & & $\begin{array}{l}\text { People at the evacuation center did not mind the radiation } \\
\text { accident; they accepted us and were kind and concerned } \\
\text { about us (2). }\end{array}$ \\
\hline & & $\begin{array}{l}\text { We were dispatched to the area that was affected by the } \\
\text { Chuetsu Earthquake; the residents told us they were victims } \\
\text { of the disaster and that we should take care of their hearts } \\
\text { (2). }\end{array}$ \\
\hline $\begin{array}{l}\text { Preparedness } \\
\text { as a city } \\
\text { employee }\end{array}$ & - & $\begin{array}{l}\text { As a city employee, I was able to accept the difficulties as a } \\
\text { part of my job (1). }\end{array}$ \\
\hline
\end{tabular}

\section{Gains from the experience}

The following four categories and seven subcategories were extracted from the interviews on evacuation shelter activities: "Increased awareness of disasters," "Growth as a nurse," "Change to a positive attitude," and "Change in relationships with people" (Table 3). Many nurses reported that the experience of supporting people at the disaster and evacuation shelters became a source of inspiration for their nursing practice. They expressed their interest in disaster nursing, including passing on the lessons learned during evacuation center activities and applying them to future disaster responses. 
Table 3

Gains from evacuation shelter activities

\begin{tabular}{|c|c|c|}
\hline Categories & Subcategories & Codes \\
\hline \multirow{8}{*}{$\begin{array}{l}\text { Increased } \\
\text { awareness of } \\
\text { disasters }\end{array}$} & \multirow{4}{*}{$\begin{array}{l}\text { Opportunity for } \\
\text { disaster nursing }\end{array}$} & DMAT is one of the certifications I got after the earthquake (2). \\
\hline & & After the earthquake, I registered as a disaster relief nurse (1). \\
\hline & & I want to be useful to someone (2). \\
\hline & & $\begin{array}{l}\text { I want to be a person who can do the same thing as the people } \\
\text { in the shelter community supported me.(2) }\end{array}$ \\
\hline & \multirow[t]{2}{*}{$\begin{array}{l}\text { Preparation for } \\
\text { disaster }\end{array}$} & $\begin{array}{l}\text { I think about how I can help when disaster strikes my location } \\
\text { (2). }\end{array}$ \\
\hline & & $\begin{array}{l}\text { I always make sure that my family is prepared for any disaster, } \\
\text { and I make use of the lessons I learned from that time, such as } \\
\text { not running out of water.(2) }\end{array}$ \\
\hline & \multirow[t]{2}{*}{$\begin{array}{l}\text { Need to pass on } \\
\text { experience }\end{array}$} & $\begin{array}{l}\text { I have been to Kumamoto to help, and my experience is } \\
\text { definitely useful (1). }\end{array}$ \\
\hline & & $\begin{array}{l}\text { I hope we can pass on our experiences to others. We have no } \\
\text { choice but to make use of the lessons we have learned ( } 2 \text { ). }\end{array}$ \\
\hline \multirow[t]{4}{*}{$\begin{array}{l}\text { Growth as a } \\
\text { nurse }\end{array}$} & $\begin{array}{l}\text { Renewed } \\
\text { awareness of } \\
\text { responsibility as a } \\
\text { nurse }\end{array}$ & I must be responsible for my work. I want to do it (3). \\
\hline & \multirow{2}{*}{$\begin{array}{l}\text { Renewed } \\
\text { recognition of the } \\
\text { purpose of } \\
\text { nursing }\end{array}$} & $\begin{array}{l}\text { I realized nurses serve inpatients as well as local residents in } \\
\text { helping maintain health (1). }\end{array}$ \\
\hline & & I have a new sense of purpose in working as a nurse (2). \\
\hline & - & It broadened my perspective as a nurse (1). \\
\hline \multirow{3}{*}{$\begin{array}{l}\text { Change to a } \\
\text { positive } \\
\text { attitude }\end{array}$} & \multirow{2}{*}{$\begin{array}{l}\text { Experience that } \\
\text { leads to the } \\
\text { present }\end{array}$} & I am here now because of my various experiences (3). \\
\hline & & I started to think positively (1). \\
\hline & Personal growth & $\begin{array}{l}\text { Despite difficulties, this experience turned out to be a blessing } \\
\text { in disguise (2). }\end{array}$ \\
\hline $\begin{array}{l}\text { Changes in } \\
\text { relationships } \\
\text { with people }\end{array}$ & - & $\begin{array}{l}\text { Since the disaster, I have interacted more with people in the } \\
\text { community (2). }\end{array}$ \\
\hline
\end{tabular}

\section{Discussion}

One of the factors that made evacuation shelter activities difficult was the stress of working in an evacuation shelter while being a disaster victim. Nurses that experienced the earthquake, tsunami, and fear of radiation exposure in the same area were also city employees directly involved with the affected 
residents. The initial confusion surrounding the earthquake may have triggered conflicting feelings about the staff's double role as relief workers and victims of the earthquake. In this context, the words of blame from the residents may have caused emotional distress among the nurses.

Previous studies have reported on the experience of first responders feeling hurt by the words of residents affected by the Great East Japan Earthquake. ${ }^{7,12-14}$ The condemnation of public officials by residents is among the characteristics of the Fukushima NPP accident. Residents may blame first responders, including nurses, seeing them as representatives of the government that may have been negligent in disaster prevention. Much has been reported about the need for aid worker support during disasters. ${ }^{10,15-18}$ Disaster response should include physical and mental health support for the victims as well as for first responders.

During evacuation shelter activities, the nurses have reported difficulties associated with performing "health activities" rather than "clinical activities"; these challenges were associated with the lack of experience in health activities. In disaster response, hospital nurses provide emergency treatment and medical care, while community nurses provide disease prevention interventions. A mismatch between expectations and competencies, and the requirements of a situation may create a sense of helplessness. ${ }^{19}$ Clinical nurses may benefit from the experience of community practice in preparation for disaster response; these opportunities may be provided by medical facilities that offer follow-up visits to discharged patients and home nursing services. This approach may help expand nurse competencies and reduce the stress associated with emergency response.

In this study, a factor that helped nurses fulfill their disaster response tasks was their willingness to do this work. Nurses tend to have high emotional intelligence and empathy, which they demonstrate in their job. ${ }^{20}$ In evacuation centers, listening to the residents is part of mental healthcare that is required; providing this type of support to disaster victims can provide nurses with job satisfaction, which increases the levels of positive self-evaluation. ${ }^{21}$ Confidence in one's own role and competencies may help nurses continue their activities at evacuation centers.

Community and clinical nurses practice in different contexts and their relationships to target populations are different although both groups have nursing responsibilities toward local residents. Clinical nurses may care for residents in home and care home settings. Clinical and community nurses should collaborate to better understand each other's roles, which may help support disaster response where both groups are involved. ${ }^{22}$

The nurses reported that support from residents and fellow staff helped their work. Encouragement from residents, expressed as warm words, helped the nurses feel accepted by the residents. Previous studies have shown that public appreciation of first responders helps them fulfill their duties, leading to recovery. ${ }^{23,24}$ The present findings are consistent with those of previous studies. 
Trauma-informed care helps trauma victims. ${ }^{25,26}$ The present study participants were able to accurately recognize traumatic events, including resident hostility, and discuss among each other the thoughts and feelings these events triggered, accounting for their mood fluctuations. This approach may have helped the nurses persevere and attend to their responsibilities. Disaster relief workers experience stress and trauma, and should be equipped with coping strategies that may be used in disaster response.

The nurses reported gaining professional insight and growth in disaster preparedness. Disaster response places a high burden on first responders that operate under the conditions of stress and chaos, which may also give them a sense of mission. First responders provide emotional support to disaster victims, which may cause stress; these circumstances create challenges that may be an opportunity for growth. Previous studies have shown that post-traumatic growth may help first responders positively view their experience of providing disaster relief. $9,27,28$ The present findings are consistent with those of previous studies. The nurses who overcame the hardship of the Great East Japan Earthquake grew as professionals, which may help them maintain staff motivation and morale in response to future disasters.

This study has some limitations, which should be considered when interpreting its findings. First, the interviews were conducted 9 years after the disaster, and some of the subjects failed to remember the disaster at the time of the interviews; therefore, the present findings may be subject to recall bias. In addition, this study did not include all employees of the Minamisoma Municipal General Hospital that were engaged in disaster response. In particular, nurses that retired during or after participating in the evacuation shelter support activities were not included, potentially reducing the generalizability of the present findings.

\section{Conclusion}

The present study participants were involved in disaster response, which required facing psychological trauma and gaps in nursing training. To improve staff management of trauma, suitable training should be provided during "normal" times to strengthen staff relationships; in addition, clinical and community nurses should be afforded opportunities to understand each other's roles to support disaster response.

\section{Abbreviations}

NPP: the Fukushima Daiichi Nuclear Power Plant

DMAT: Disaster Medial Assistance Team

\section{Declarations}

Acknowledgements 
We would like to thank all the nursing managers and staffs who kindly cooperated for the interviews. We would like to thank Ms. Chieri Yamada of Fukushima Medical University Graduate School for her advice on our research. We are also grateful to Mr. Masatsugu Tanaki of Minamisoma Municipal General Hospital for his technical support and Ms. Yuka Harada of Department of Radiation Health Management, Fukushima Medical University School of Medicine, for her administrative support.

\section{Authors' contributions}

$\mathrm{CY}$ was responsible for the conception and design of the study. $\mathrm{CY}$ conducted the interviews and was involved in the preparation and revision of the manuscript. $\mathrm{KO}, \mathrm{AH}, \mathrm{TO}$ and MT contributed to supervision in drafting and revising. All authors have approved the submitted version of the manuscript, and agreed to be personally accountable for the author's own contributions and to ensure that questions related to any part of the work are appropriately investigated and resolved.

\section{Funding}

Not applicable.

Availability of data and materials

Not applicable.

\section{Ethics approval and consent to participate}

The research ethics was approved Minamisoma Municipal General Hospital Ethics Committee and the Ethics Committee of the Fukushima Medical University. The informed consent was obtained from all participants on written forms.

\section{Consent for publication}

As all the interview data were anonymized, the consent for publication is not applicable for this research

Competing interests

The authors declare that they have no competing interests

\section{References}

1. Kazumasa N. et al. Factors causing hypertension in evacuation centers at the time of disaster and current status and issues regarding cardiovascular disease physicians Mie Journal of Nursing 2020;22:51-58.

2. Hiromi N. et al. A study of pressure ulcers that occurred in evacuation centers in Miyagi Prefecture during the Great East Japan Earthquake and the factors that led to their occurrence Journal of the Japanese Society for Group Disaster Medicine 2012;17(1):225-233. 
3. Disaster Area Support and Disaster Relief Volunteer Information: Great East Japan Earthquake Number of Volunteers in Iwate, Miyagi, and Fukushima Prefectures, Japan National Council of Social Welfare 2018.3.

4. Nahoko $\mathrm{H}$ et al. Activities, duration of activities, and psychological state after returning to the hospital of a private medical volunteer group in the Great East Japan Earthquake Journal of the Japanese Society for Behavioral Science in Health Care 2014;29(1):40-47.

5. Akiko $O$ et al. Psychological effects of relief activities in Ofunato City, Iwate Prefecture, on general volunteers: From the experience of a private hospital that has been engaged in activities at an evacuation center - Japanese Journal of Counseling Science 2014;47(4).

6. Yumiko $\mathrm{N}$ et al. Public health nurses' activities and future preparedness for nuclear disaster caused by the Fukushima Daiichi Nuclear Power Plant accident Bulletin of the Department of Medicine and Health Sciences, Tohoku University 2014;23(1):27-38.

7. Yasuyuki $Y$ et al. Psychological stress of local government employees responding to disasters in the areas affected by the Great East Japan Earthquake: From the results of a mental health survey conducted in the first year after the disaster - Labor Science 2017;93(3):80-94.

8. Tatsuo $S$ et al. Posttraumatic stress symptoms of disaster medical supporters in the Great East Japan Earthquake: Relationship between controllability of intrusive recall symptoms and posttraumatic stress symptoms Behavioral Medicine 2013;19(1):3-10.

9. Hiroko $S$ et al. Psychological status of disaster medical supporters in the Great East Japan Earthquake Journal of St. Luke's College of Nursing 2015.1;18(2)

10. Kazuma Y. Stress problems in psychiatric insurance welfare activities after the Great East Japan Earthquake -Stress problems and support for supporters in Soso district, Fukushima PrefectureIndustrial Stress Research 2014.10;21(4).

11. Takami T. Methodology of qualitative research - For scientific analysis of qualitative data - Journal of the Japanese Society of Radiological Technology 2011.4;413-417

12. Hiroko Kuwabara et al. Post-traumatic stress response of municipal employees affected by the Great East Japan Earthquake Traumatic Stress 2015.12;12(2)

13. Yutaka Matsui Catastrophic stress of disaster relief workers in the Great East Japan Earthquake Stress Science 2019;33(4):311-321

14. Ryusuke Takagi Survey on the Actual Condition of Local Government Employees Affected by the Nuclear Power Plant (2nd round) Jichi Research Institute Notice 2018.5;475:48-91

15. Noriko $\mathrm{N}$ Mental health care and community health welfare activities at the time of disaster Jishokusai Medical Journal 2013;61:100-104

16. Harumi $Y$ et al. A survey on mental and physical health of public health nurses dispatched to disaster relief activities after the Great East Japan Earthquake Mental and Physical Health Science 2013;9(1):26-36

17. Yamashita K. et al. Needs change and current situation of reconstruction supporters in Fukushima Prefecture after the Great East Japan Earthquake Traumatic Stress 2014.;12(1) 
18. Akiko Sakurai et al. Disaster support and physical and mental care of local government employees: From the reconstruction of the Great Hanshin-Awaji Earthquake to the Great East Japan Earthquake and other disaster areas at home and abroad Psychosomatic Medicine 2017;57(3):243-250

19. Aoki, M. et al. Perceptions of Nurses' Roles for Health Care Needs in All Disasters: A Comparison of Perceptions between Nurses Working in Hospitals and Nurses Working in the Community - Japan Disaster Nursing 2006;8(2):20-33

20. Itoko $Y$ et al. Effects of alexithymia and social support on nurses' emotional labor: Program of the Annual Meeting of the North Japan Society of Nursing 2010;12:81-93

21. Setou N. et al. Factors related to the fatigue of relief workers in areas affected by the Great East Japan Earthquake: survey results 2.5 years after the disaster Disaster BioPsychoSocial Medicine Vol.12 No.14

22. Yonetoshi $\mathrm{N}$ et al. Effect of incorporating group work with public health nurses in training for disaster relief nurses Japanese Journal of Disaster Medicine 2017;22:71-78

23. Tatsuie Y. Support for nurses who carried out their duties while suffering from the disaster by stress of the disaster Occupational Mental Health 2013.3;21(1):4-8

24. Jun S. Significance of rescuers and supporters in the Great East Japan Earthquake Traumatic Stress 2012;10(1)

25. Yuko N. Trauma-informed care: An approach to enhance safety from a public health perspective Traumatic Stress 2019.6;17(1):80-89

26. Yuka O. "Practice of trauma-informed care linking "people, community, and society" Mental Health Welfare 2020;51(1):83

27. Eimi O. et al. A Study on Secondary Injury and Mental Health Measures of Disaster Relief Workers Journal of Nagano Prefectural College of Nursing 2007;9:19-27

28. Liao SC et al. Association of psychological distress with psychological factors in rescue workers within two months after a major earthquake. Journal of Formosan Medical Association. 2002;101(3):169-176

\section{Figures}




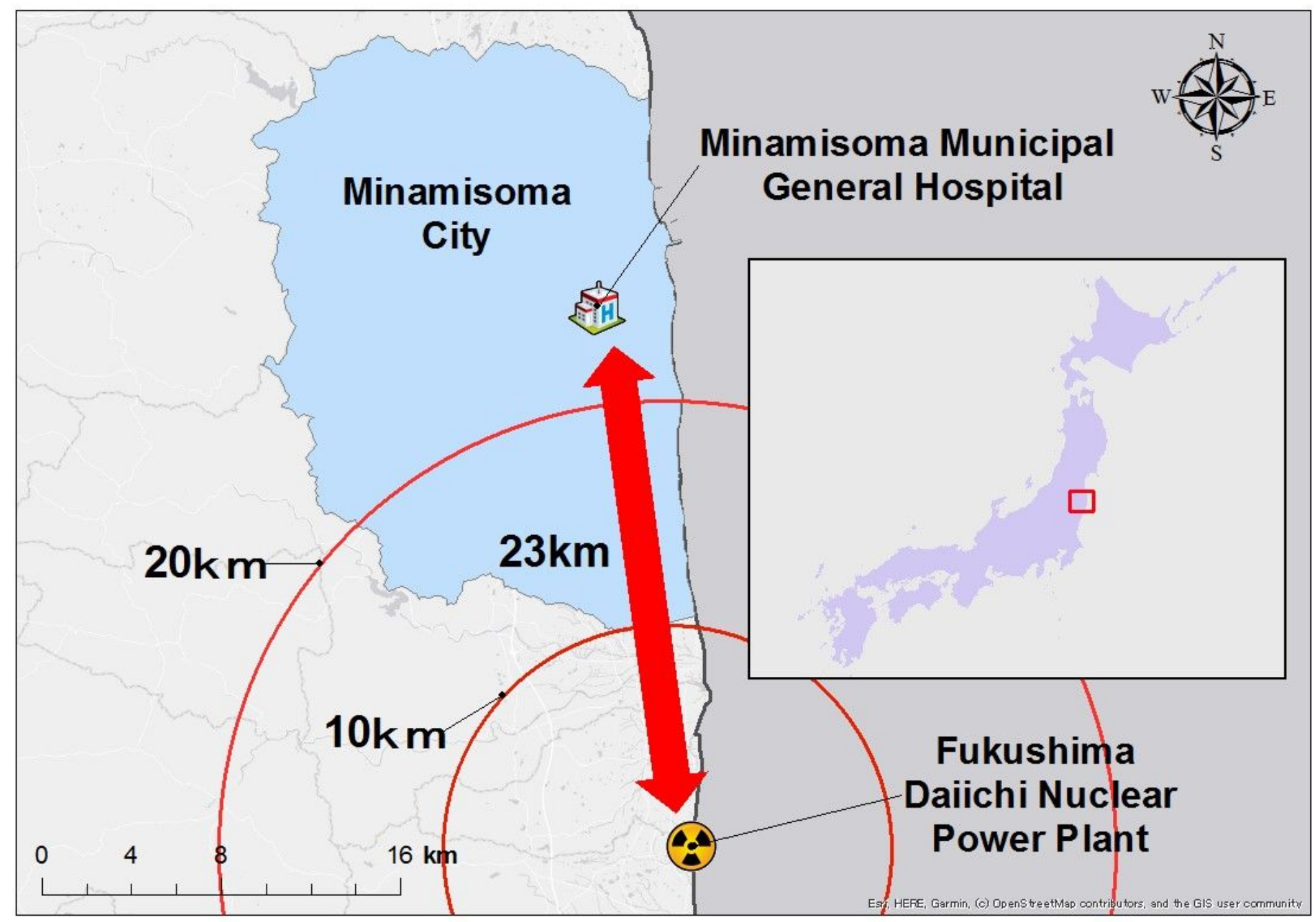

Figure 1

On March 12, evacuation orders were issued to residents within a 20-km radius of the Fukushima nuclear power plant. On March 15, indoor evacuation orders were issued to residents within a 20 - to $30-\mathrm{km}$ radius. 